\title{
항만공진주기와 선박동요량을 고려한 항만가동율 산정 Evaluation of Effective Working Days in a Harbor Considering Harbor Resonance and Moored Ship Motion
}

\author{
곽문수* · 문용호** \\ Moonsu Kwak* and Yongho Moon**
}

\begin{abstract}
요 지 : 본 연구는 선박의 크기, 계류조건, 파랑의 주기, 파향 등에 의한 계류선박의 동요량을 해석하고 선박의 하 역한계파고 산정 및 항만가동율을 평가하는 방법을 제시한 것이다. 본 방법은 포항신항 제 8 부두의 파랑관측자료를 이용하여 타당성을 검증하였다. 하역중단 시 파랑관측 자료는 파고 $0.10 ~ 0.75 \mathrm{~m}$, 주기 $7 \sim 13 \mathrm{~s}$ 이었으며, 이때 계류 된 선박은 800 35,000톤 이었다. 그리고 본 방법으로부터 산정된 제 8 부두의 하역한계파고는 선박 $5,000,10,000$, 30,000 톤에 대하여 파고 $0.19 \sim 0.50 \mathrm{~m}$, 주기 8 12 s로 산정되었다. 본 방법의 결과는 연구대상 선박의 크기가 현지 선박의 크기와 정확히 일치하지는 않아서 파고는 관측치와 다소 차이를 보이지만 주기변화에 따라 하역한계파고를 잘 재현하고 있음을 알 수 있었다. 그리고 파향이 75 도 인 경우의 본 방법에 의한 하역한계파고는 현행 항만설계 기준에 제시된 한계파고 보다 장단주기 파를 고려하면 16 62\% 감소하였고, 단주기 파랑만 고려하면 $0 \sim 46 \%$ 감소하 였다. 특히 현행 항만설계기준의 하역한계하고는 10,000 톤 이하의 선박에 대해서는 과대 평가되었음을 확인할 수 있 었다. 한편, 선박의 동요량을 고려하여 산정된 포항신항 제 8 부두의 가동율은 설계기준 파고에 의한 가동율 에 비 하여 $6.5 \%$ 감소하였다.
\end{abstract}

핵심용어 : 하역한계파고, 선박동요량, 선박동요해석모형, 항만가동율, 포항신항

\begin{abstract}
This study proposed an estimation method of allowable wave height for loading and unloading of the ship and evaluation of effective working days considering moored ship motion that is affected by sip sizes, mooring conditions, wave periods and directions. The method was examined validity by comparison with wave field data at pier $8^{\text {th }}$ in Pohang New Harbor. The wave field data obtained with wave height of $0.10 \sim 0.75 \mathrm{~m}$ and wave period of $7 \sim 13 \mathrm{~s}$ in ship sizes of 800 35,000 ton when a downtimes have occurred. On the other hand, the results of allowable wave height for loading and unloading of the ship in this method have obtained with wave heights of $0.19 \sim 0.50 \mathrm{~m}$ and wave periods of $8 \sim 12 \mathrm{~s}$ for ship sizes of 5,000, 10,000 and 30,000 ton. Thus this method well reproduced the field data respond to various a ship sizes and wave periods. And the results of this in Korea are didn't respond to various the ship sizes and wave periods, and we $\mathrm{h}$ method tended to decrease in 16 62 percent when have considered long wave, and it is decreased in 0 46 percent when didn't consider long wave than design standards in case of the ship sizes of 5,000 30,000 ton, wave period of $12 \mathrm{~s}$ and wave angle of $75^{\circ}$. The allowable wave heights for loading and unloading of the ship proposed by design standards in Korea have found that overestimated on smaller than 10,000 ton. On the other hand, the rate of effective working days considering ship motion at pier $8^{\text {th }}$ in Pohang New Harbor reduced in 6.5 percent when compare with the results without considering ship motion.
\end{abstract}

Keywords : Allowable wave height for loading and unloading of ship, Oscillation quantity of moored ship, ship model for analysis of moored ship motion, effective working days in a harbor, Pohang New harbor

\section{1. 서 론}

항만 설계 기준은 연간 $97.5 \%$ 이상의 항만가동율을 확보 하도록 규정하고 있으며, 계류시설 전면의 하역한계파고는 소 형선 $0.3 \mathrm{~m}$, 중대형선 $0.5 \mathrm{~m}$, 초대형선 $0.7 \sim 1.5 \mathrm{~m}$ 로 되어 있 다. 하역한계파고는 하역허용파고라는 의미로도 사용되며, 계
류시설 전면의 파고가 하역한계파고를 초과하면 하역작업이 불가능함을 의미하는 파고로서 항내정온도 및 항만가동율 산 정의 기준이 되는 값이다. 설계기준에 제시된 하역한계파고 는 선박의 크기를 3 개 등급으로 구분하고 각 등급은 일률적 인 파고 값을 적용하고 있으나, 현지에서 하역중단을 발생시 키는 파고는 선박의 크기, 계류시스템의 상태, 파랑의 주기 및

*명지전문대학교 토목공학과 교수 (Corresponding author: Department of Civil Engineering, Myongji College, Seoul 120-776, Korea, Tel: 02300-1290, Fax: 02-303-1132, moonsu@mjc.ac.kr)

**대영 엔지니어링 기술연구소 (DY Engineering Co., 13th fl. Kolon Science Valley 1, Seoul 152-050, Korea, jau84@hanmail.net) 
파향, 기상 등 많은 요소에 의해서 달라진다. 특히, 항 입구 의 폭이 항내 수면적에 비해 매우 좁은 경우나, 장방형의 항 내 슬립에서는 선박의 고유주기와 유사한 장주기 또는 외중 력파 성분이 입사하면 공진현상이 발생하고 선박의 동요를 증 가시켜서 하역중단을 일으키는 사례도 발생한다. 이러한 장주 기 파랑의 영향은 선형이 커질 수록 하역중단에 결정적인 요 인으로 작용하기도 한다. 따라서, 하역한계파고를 현지 파랑 과 부합되도록 산정하기 위해서는 선박의 크기, 계류상태, 단 주기파 및 장주기파의 영향 등을 반영하여 산정할 필요가 하 다. 그리고 선박의 동요량을 고려하여 산정된 하역한계파고는 실해역의 하역가동률 평가에 매우 유용하게 사용될 수 있다.

계류선박의 동요량을 해석하고 평가한 연구로는 Ueda and Shiraishi (1988)가 계류선박의 동요를 고려한 하역가동률 계 산법을 제시하였다. 이 계산법은 선박의 하역허용 동요량에 의해 선석 전면에서의 하역한계파고를 파향 및 주기 별로 도 출하고, 항내 파고를 계산하여 하역가능 심해파고의 비 초과 확률을 구한 후 각 선석에서 하역가동률을 산정 한 것이다. Kubo et al. (1993)은 Ueda and Shiraishi (1988)가 제시한 계산법은 유효하지만 막대한 계산이 요구되고, 하역가동률이 파랑, 바람 등의 외력 뿐만 아니라 계류시스템의 특성에 의 해서도 크게 좌우되는 것을 인지하고 선박 동요 모형를 사용 하여 하역가동률을 간이적으로 산정 할 수 있는 개략식을 제 안하였다. 특히 동요에 영향을 주는 인자 중 계류시스템의 주 특성 인자인 방충공에 대해서 평가하였다. Ueda et al. (1994)은 선박의 동요 및 이미 제안한 하역한계파고를 이용 하여 하역가동률을 산정 하였으며 대상 해역에서 선박 동요 에 가장 큰 영향을 미치는 인자를 파악하였다. Kubo and Sakakibara (1995)는 파군과 부진동에 의한 장주기 파랑이 항 만가동율에 미치는 영향을 선박 동요 관점에서 평가하였다. 여기서는 대상 선박의 Surge 동요 고유주기와 장주기파의 주 기가 비슷한 경우에 상호작용을 일으켜 동요가 크게 증가하 고 항만가동율을 저하시키는 요인임을 지적하였다. 최근 Sakakibara et al. (2001)은 카메라를 사용하여 선박 동요량을 계측하고 수치모형으로 동요량의 시계열 해석을 하였다. 그리 고 Mollen et al. (2003)은 선박동요 수치계산 결과와 실제 관 측된 복원력을 비교하고 동요량과 일치함을 보였다. 한편, Cho et al. (2006)은 쓰나미를 대상으로 하여 항내 계류 중인 선 박의 거동에 대한 수치시뮬레이션을 수행하여 쓰나미에 의한 선박 운동의 영향 및 계류삭과 펜더에 작용하는 계류 하중을 계산하였으며, Kwak et al. (2006)은 단주기 파랑이 작용할 때 계류선박의 동요량을 산정하여 하역가동률을 평가하는 방 법을 제시하였다.

본 연구에서는 항만 공진해석과 선박 동요량 해석을 실시 하여 단주기 파랑과 항만 공진주기에 해당하는 장주기 파랑 이 선체에 작용할 때 선석 전면에서 선형별, 주기별, 파랑의 입사각도별 하역한계파고를 산정하는 방법을 제시하고자 한 다. 여기서는 포항신항의 제 8 부두에 대하여 본 방법을 적용
하고 하역중단 시 관측된 현지 파랑 관측자료 및 설계기준에 제시된 하역한계파고와 비교하여 본 방법의 타당성을 검증하 고자 한다. 나아가 선박의 동요량을 고려하여 산정된 하역한 계파고를 사용하여 포항신항 제 8 부두의 가동률을 평가하고 현행 항만설계기준에 의한 가동율 결과와 비교하여 현행 항 만가동율 평가 방법의 문제점을 파악하고자 한다.

\section{2. 선박 동요량을 고려한 하역한계파고 산정 방법}

선박 동요랑을 고려한 하역한계파고 산정 방법은 단주기 및 장주기 파랑에 의한 계류 선박의 동요량을 계산하고, 하역 가능 여부를 판단할 수 있는 하역허용 동요량을 이용하여 선종, 선 형, 파향, 주기별로 하역이 가능한 한계파고를 산정하는 것이 다. 이 방법을 구체적으로 설명하면, 먼저 선형마다 파랑조건 및 계류조건 등을 달리하여 계류 선박의 동요 시뮬레이션을 수행한다. 다음은 선체 입사 파고와 동요량이 대체적으로 선 형 관계에 있으므로 각 주기 별로 양자의 관계에 대한 회귀 식을 구한다. 이 회귀식과 하역허용 동요량과의 교점에 해당 하는 파고가 하역한계파고 이며 이것을 주기별로 구한다. 이 러한 과정은 각 동요 성분별로 반복하여 적용된다. 또한 방 현재에 대해서는 방현재의 최대변위가 허용변위를 넘지 않는 파고를 구하고 이를 하역한계파고로 한다 (Fig. 1). 여기서 하 역허용동요량은 Table 1과 같으며, 표에서 일반화물선, 유조 선(내항 및 외항), 곡물운반선, 광석운반선은 Ueda and Shiraisi (1988)가 제안한 값이고, 그 이외의 선종은 Bruun (1981)이 제안한 값이다.

최종 하역한계파고는 각 동요 성분별 및 방현재의 최대 변

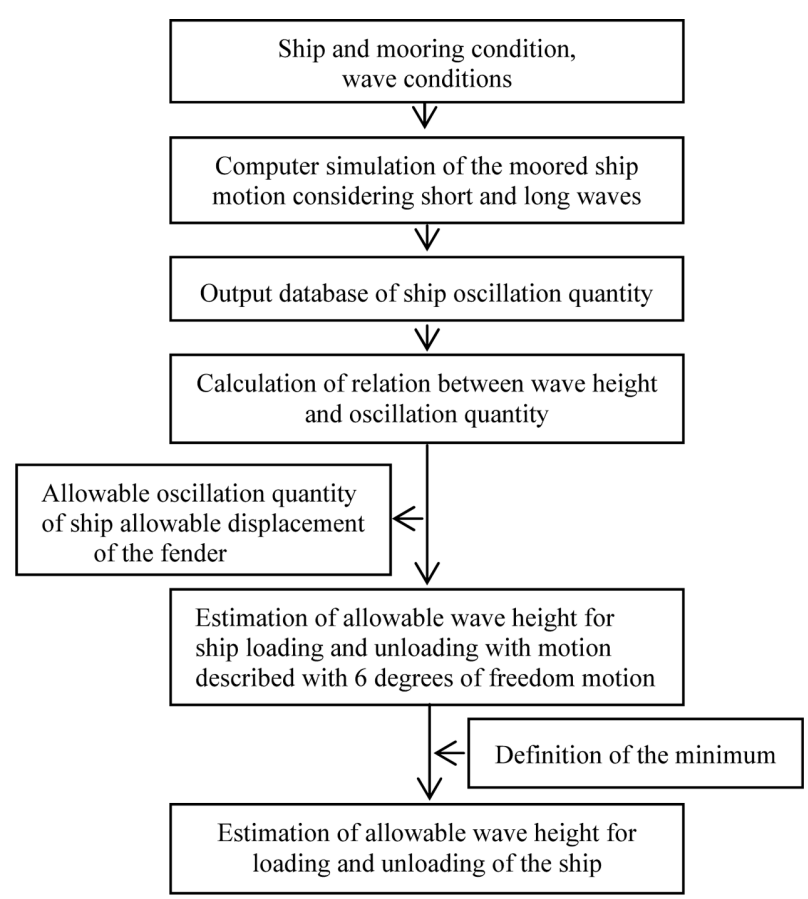

Fig. 1. Estimation process on allowable wave height for loading and unloading of the ship considering ship motion. 
Table 1. Allowable oscillation quantity of ship motion for loading and unloading

\begin{tabular}{ccccccc}
\hline \hline Type of ship & $\begin{array}{c}\text { Surge } \\
(\mathrm{m})\end{array}$ & $\begin{array}{c}\text { Sway } \\
(\mathrm{m})\end{array}$ & $\begin{array}{c}\text { Heave } \\
(\mathrm{m})\end{array}$ & $\begin{array}{c}\text { Roll } \\
\left({ }^{\circ}\right)\end{array}$ & $\begin{array}{c}\text { Pitch } \\
\left({ }^{\circ}\right)\end{array}$ & $\begin{array}{c}\text { Yaw } \\
\left({ }^{\circ}\right)\end{array}$ \\
\hline $\begin{array}{c}\text { General } \\
\text { cargo ship* }\end{array}$ & \pm 1.0 & +0.75 & \pm 0.5 & \pm 2.5 & \pm 1.0 & \pm 1.5 \\
$\begin{array}{c}\text { Grain carrier* } \\
\text { Ore carrier* }\end{array}$ & \pm 1.0 & +0.5 & \pm 0.5 & \pm 1.0 & \pm 1.0 & \pm 1.0 \\
$\begin{array}{c}\text { Oil tanker* } \\
\text { (outer harbor) }\end{array}$ & \pm 1.0 & +0.75 & \pm 0.5 & \pm 4.0 & \pm 2.0 & \pm 2.0 \\
$\begin{array}{c}\text { Oil tanker* } \\
\text { (inner harbor) }\end{array}$ & \pm 1.5 & +0.75 & \pm 0.5 & \pm 3.0 & \pm 1.5 & \pm 1.5 \\
$\begin{array}{c}\text { Container ship** } \\
\text { (L0/L0) }\end{array}$ & \pm 0.5 & +0.3 & \pm 0.3 & - & - & - \\
Container ship** & \pm 0.3 & +0.2 & \pm 0.1 & - & - & - \\
$\begin{array}{c}\text { (R0/R0-Side) } \\
\text { Car carrier** }\end{array}$ & \pm 0.3 & +0.2 & \pm 0.1 & - & - & - \\
\hline
\end{tabular}

*proposed by Ueda and Shiraishi(1988),

**proposed by Bruun(1981)

위로부터 구해진 하역허용파고를 비교하여 그 최소값을 해당 조건의 하역한계파고로 한다. 단, 이 파고 값이 현행 설계기 준에 제시된 하역한계파고를 초과할 때는 설계기준의 값을 하 역한계파고로 한다.

\section{3. 선박 동요 해석 모형}

\section{1 기본방정식}

유체 중에서 계류된 선체에 작용하는 힘으로는 선체의 운 동에 의해 발생하는 유체 동력학적 힘과 유체 정력학적 힘, 입사파에 의해 선체에 작용하는 파 강제력, 계류장치에 의해 작용하는 계류력 등이 있다. 여기서 파 강제력이란 동유체력 들 중 하나이고 선박을 향해 다가오는 파들에 의해 배가 받 는 힘을 이야기 한다. 이러한 힘들을 이론적으로 정확하게 구 하기는 불가능하다. 그러므로 여러 가지 가정을 함으로써 물 리적 모델을 계산이 가능한 수학적 모델로 바꾸어야 한다.

본 연구에 사용된 모형에서는 속도포텐셜을 도입한 후 선체 의 운동이 미소하다고 가정하여 선체의 운동을 변수로 하여 유 체의 동력학적 힘과 파 강제력을 선형화하여 구하였다. 실제 의 해상상태는 매우 불규칙적이어서 선박의 운동을 직접 관 측 하는 것은 매우 복잡하다. 그러므로 파고가 작다고 가정 하여 불규칙적인 해상상태를 규칙적인 선형파들의 중첩으로 생각하여, 규칙파 중에서의 선체운동을 계산한 후 스펙트럼 해석을 통하여 불규칙파 중에서의 운동을 예측한다. 본 연구 에서는 유의파고와 특성주기의 변수로서 표현이 가능한 Bretschneider 스펙트럼을 이용하여 불규칙 해상상태를 가정 하였다.

선박의 계류장치로는 계류삭과 방현재가 있는데 두 가지 모 두 선체의 운동에 대해 비선형성을 갖는다. 그러나 본 연구에
서는 주파수 영역에서의 선체의 운동을 해석하기 위해서 이들 이 운동에 대해 선형성을 갖는다고 가정하여 계류력을 구하였 다. 규칙파 중에서 선체의 선형운동 방정식은 식 (1)과 같다.

$$
\left[-\omega^{2}\left(M_{j k}+A_{j k}\right)+i \omega B_{j k}+R_{j k}\right] a_{k}=F_{j}
$$

여기서, $M_{j k}=$ 선체의 질량, $A_{j k}=$ 선체부가질량, $B_{j k}=$ 감쇠계 수, $R_{j k}=$ 복원력, $\omega=$ 파 진동수, $i=\sqrt{-1}, a_{k}=$ 선체운동의 진폭, $F_{j}=$ 파 강제력

위 식에서 선체에 작용하는 유체력으로는 부가질량과 감쇠 력으로 나타내어지는 동유체력, 파랑에 의해 작용하는 파 강 제력, 선체 운동에 의해 발생하는 부력의 변화에 의해 선체 에 작용하는 유체 정력학적 힘이 있다. 또한 계류장치에 작 용하는 계류력이 선박의 운동에 대해 복원력으로 작용한다 (Ann, 1986 ; Ann and Rhee, 1987).

본 연구에서 사용한 선박 동요 해석 모델은 Ann (1986), Ann and Rhee (1987)가 개발한 Green 함수 모형을 기초로 하여 단주기 및 장주기 파랑에 의한 동요 해석이 가능하도록 장단주기 파랑의 파 강제력을 각각 구하여 합성하는 부분을 추가한 것이다. 본 모형은 기본방정식을 적분방정식으로 변 환하여 해를 구하는 Green 함수법을 사용하여 방사문제와 산 란문제를 풀게 된다. 특히, Green 함수법은 적분방정식을 경 계치 문제로 풀게 되므로 주어진 경계조건으로 경계치를 미 리 산정해 놓으면 계산시간이 매우 짧아지며, Green 함수를 이용하여 두 물체의 상호 영향력을 해석하므로 안벽과 부유 체의 상호 거동 해석에 매우 편리하다.

\section{2 동유체력과 파 강제력}

식(1)에서 $A_{j k}$ 와 $B_{j k}$ 는 선박의 $k$ 방향 운동에 의하여 선체 에 작용하는 $j$ 방향의 동유체력이고, $F_{j}$ 는 입사파에 의해 선 박에 작용하는 파 강제력이다. 이 힘들을 물리적으로 구하기 위해서는 여러 가지 가정들을 도입하여 계산이 가능한 수학 적 모델로 만들어야 한다. 먼저 유체는 비점성, 비압축성으로 가정하고 유체의 비회전성으로 가정하여 속도포텐샬을 도입 한다. 파고는 작다고 가정하여 선형파 이론을 적용하고 동시 에 선체의 운동이 작다는 가정을 도입함으로써 다음과 같이 속도포텐샬을 분리한다.

$$
\Phi=\Phi_{0}+\Phi_{7}+\sum_{i=1}^{6} \Phi_{i}
$$

여기서, $\Phi_{0}=$ 입사파의 속도포텐샬, $\Phi_{7}=$ 입사파의 선체에 의한 산란 속도포텐샬, $\Phi_{i}=i$ 모드의 선체운동에 의한 방사 속도포텐샬

이러한 속도포텐샬들은 이상 점 분포(singularity distribution) 를 이용한 다음과 같은 적분방정식을 이용하여 구할 수 있다.

$$
\Phi_{i}(P)=-\frac{1}{4 \pi} \iint_{S_{1}+S_{2}} \sigma_{i}(Q) G(P, Q) d s(Q)
$$




$$
\frac{\partial \Phi_{i}(P)}{\partial n_{P}}=-\frac{\sigma_{i}(P)}{2}-\frac{1}{4 \pi} \iint_{S_{1}+S_{2}} \sigma(Q) \frac{\partial G(P, Q)}{\partial n_{P}} d s(Q)
$$

여기서, $S_{1}$ 선체의 침수표면, $S_{2}=$ 안벽(jetty)의 침수표면, $\sigma=$ 용출 점의 세기, $n_{P}=P$ 점에서 유체장 밖으로 향한 단위 법선, $G(P, Q)=$ Green 함수 $(Q$ 에 위치한 단위 용출 점에 의 한 $P$ 에서의 속도포텐샬)

방사문제에서는 정수 중에서 선박과 안벽 간의 상호 작용 하는 유체력으로 이루어져 있다. 이 유체력을 구하기 위해 서는 다음과 같은 경계조건이 주어져야 한다. 식 (4)의 물체 표면에서의 경계조건은 방사문제에서는 다음 식과 같이 주 어진다.

$$
\frac{\partial \Phi_{i}(P)}{\partial n_{P}}=\left\{\begin{array}{cc}
i \omega a_{i} n_{i}(P) & P \in S_{1} \\
0 & P \in S_{2}
\end{array}\right.
$$

산란문제에서는 파랑중에서 선박이 움직이지 않도록 구속 시키고 푼다. 지배방정식, 자유표면조건, 방사조건, 해저경계 조건은 산란문제와 동일하고, 선체경계조건만 다르다. 선체경 계조건은 다음과 같다.

$$
\frac{\partial \Phi_{7}(P)}{\partial n_{P}}=-\frac{\partial \Phi_{0}(P)}{\partial n_{P}} \quad P \in S_{1}+S_{2}
$$

또한, Green함수는 다음과 같은 형태의 유한수심에서의 단 위 용출 점에 대한 함수를 사용한다.

$$
\begin{aligned}
& G(P, Q)=\frac{1}{r}+\frac{1}{r_{1}} \\
& +2 \int_{0}^{\infty} \frac{(k+v) e^{-k h} \cosh k(\zeta+h) \cosh k(z+h)}{k \sinh k h-v \cos h k h} \\
& \times J_{0}(k R) d k \\
& +2 \pi i \frac{(k+v) e^{-k h} \cosh k(\zeta+h) \cosh k(z+h)}{v h-\sinh ^{2} k h} \\
& \times J_{0}(k R) \quad \\
& =\frac{2 \pi\left(v^{2}-k^{2}\right)}{\left(k^{2}-v^{2}\right) h+v} \cosh k(\zeta+h) \cosh k(z+h) \\
& \times\left[Y_{0}(k R)+i J_{0}(k R)\right] \\
& +4 \sum_{i=1}^{\infty} \frac{k_{i}^{2}+v^{2}}{\left(k_{i}^{2}+v^{2}\right) h-v} \\
& \times \cos k_{i}(\zeta+h) \cos k_{i}(z+h) k_{0}\left(k_{i} R\right)
\end{aligned}
$$

여기서, $\mathrm{P}=(x, y, z), \mathrm{Q}=(\xi, \eta, \zeta), \mathrm{r}=(x-\xi)^{2}+(y-\eta)^{2}$ $+(z-\zeta)^{2}, r_{1}=(x-\xi)^{2}+(y-\eta)^{2}+(z+2 h+\zeta)^{2}, R=(x-\xi)^{2}$ $+(y-\eta)^{2}, v=\omega^{2} / g, h=$ 수심, $k=$ 파수, $v=k \tanh k h$ 를 만족하는 실근, $k_{i}=$ 파수, $v=k_{i} \tanh k_{i} h$ 를 만족하는 실근

위의 식 (6)은 수평거리가 가까울 경우에 사용하고, 식 (7) 은 수평거리가 비교적 먼 경우에 사용하는 것이 편리하다. Green 함수의 해로 주어지는 Bessel 함수는 용출 점에 가까 울 수록 무한대로 발산하는 성질이 있다. 따라서 Green 함수
모형에서는 두 점의 수평거리가 가까울 때와 먼 때를 분리하 여 계산하고 있으며, 그 경계 값은 무차원 수 $k R$ 로 구분하고 있다. 수치계산에서는 두 점의 거리가 가까울 때 발산하는 해 를 수렴하도록 근사적으로 풀어야 하며, 본 연구에서는 식 (6) 을 사용하여 Green 함수 해를 구하도록 하고 있다. 해가 발 산하는 경계는 여러 번의 시험계산을 통하여 정하게 되고, 본 연구에서는 이 경계로써 $k R=0.05$ 로 주었다.

이와 같이 속도포텐샬이 구해지면 이 속도포텐살을 선형화 된 Beruoulli 방정식에 대입하여 다음과 같이 유체 동압력을 구할 수 있다.

$$
p=-i \omega \rho \Phi
$$

식 (8)을 정수압으로 무차원화 하면

$$
\frac{p}{\rho g a}=\frac{\omega^{2}}{g} \frac{1}{i \omega a} \Phi
$$

이 되고, 다음과 같이 무차원화된 동압력 $p^{\prime}$ 를 얻을 수 있다.

$$
p^{\prime}=\frac{p}{\rho g a}=v \phi
$$

여기서, $\phi$ 는 무차원화된 속도포텐샬로써

$$
\phi=\frac{1}{i \omega a} \Phi
$$

로 표시된다.

식 (9)를 선체표면에 대하여 적분하면 방사문제에서는 부 가질량과 감쇠계수를 구할 수 있고, 산란문제에서는 파 강제 력을 구할 수 있다.

\section{3 복원력}

계류된 선박이 운동을 하면 선체는 선박의 운동에 따른 부 력의 변화에 의해 발생하는 정유체력과 계류장치에 의한 강 성력이 복원력으로 작용한다. 계류장치에는 계류삭과 펜더가 있는데 이들을 모두 선형 스프링장치로 가정하여 복원력을 구 한다. 정유체력에 의한 복원력 계수는 원점을 무게중심에 취 하였을 경우 다음과 같다.

$$
\begin{aligned}
& C_{33}=\rho g S \\
& C_{44}=\rho g \tilde{V}\left[\left(S_{22} / \tilde{V}\right)-B G\right] \\
& C_{55}=\rho g \tilde{V}\left[\left(S_{11} / \tilde{V}\right)-B G\right]
\end{aligned}
$$

이 식에서 $S$ 는 수선면적을, $S_{11}$ 과 $S_{22}$ 는 각각 종 방향 2 차 모멘트와 횡 방향 2 차 모멘트를 나타낸다. 또한 $\tilde{V}$ 는 선박의 배수용적을 나타내고, $B G$ 는 부심에서 무게 중심까지의 연직 높이이다. 위 식의 3 항을 제외한 나머지 계수는 모두 0 을 취 하면 된다. 


\section{4 관성력}

물체가 관성운동을 하면 물체는 가속도에 비례하는 관성력 을 갖게 된다. 본 모형의 경우에도 선박이 정현 운동을 하게 되므로 관성력이 존재한다. 선박의 운동방정식에서 보면 이 힘에 관계하는 계수는 $M_{j k}$ 이다. 이 계수의 각 성분은 다음 과 같다.

$$
\begin{aligned}
& M_{11}=M_{22}=M_{33}=\rho \tilde{V} \\
& M_{44}=I_{11} \\
& M_{55}=I_{55} \\
& M_{66}=I_{66} \\
& M_{46}=M_{64}=I_{46}
\end{aligned}
$$

여기서, $I_{j k}=\iiint_{\tilde{V} S} \rho_{B}\left[\vec{X} \cdot \vec{X} \delta_{i j}-X_{i} X_{j}\right] d \tilde{V}, \vec{X}=$ 거리 벡터, $\delta_{i j}=$ Krone-cker Delta 함수 $(i=j$ 이면 $1, i \neq j$ 이면 0$)$, $\rho_{B}=$ 선체의 질량 밀도

이 식은 원점을 선박의 무게 중심에 취하였을 경우의 식이 고, 다른 위치에 원점을 취할 경우는 나타낸 항들 이외에도 다른 항들이 다수 포함되어야 한다.

한편, 본 모형의 검증은 Sakakibara et al. (2001)이 실시한 동요량의 현지 계측 결과 및 Kubo et al. (1988)의 모형과 비교하여 실시하였으며, 검증 결과는 Kwak et al. (2013)에 제시되어 있다.

\section{4. 계류선박의 동요량 계산}

\section{1 동요량 계산 조건}

본 연구에서는 포항신항 제 8 부두의 항내 슬립에 위치한 선 석을 대상으로 일반화물선 5,000톤, 10,000 톤, 30,000 톤에 대 하여 동요량을 계산하였다. Fig. 2는 항만공진해석을 위한 계 산영역과 선박동요해석을 위한 계류선박의 위치를 나타낸 것 이다. 계류선박은 계류 장치에 의한 복원력이 동요량에 큰 영 향을 미치므로 동요 해석에 있어서 계류시스템의 특성을 수
치모형에서 잘 재현할 필요가 있다. Fig. 3은 수치계산에 사 용된 선박의 계류시스템 및 파랑의 입사각도를 정의한 모식도 이다. 본 논문에서는 계류삭과 방현재의 계류장치에 대한 입력 정보를 반영하여 계류장치에 의한 복원력을 해석하였다. 계류 삭과 방현재의 입력정보는 선인장력, 탄성계수, 계류력이 작용 하는 위치좌표, 계류삭의 경사각 및 회전각 등이 주어졌다. 그 밖에 선박의 동요해석에 사용된 선박의 제원 및 계류삭, 방현 재의 수를 정리하면 Table 2와 같다.

본 연구 대상 지역인 포항신항 제 8 부두의 항내 슬립 안 쪽은 안벽에 의한 다중반사로 공진현상이 뚜렷하며 장주기 및 단주기 파랑이 중복파를 형성한다. 항내 슬립에 계류된 선체 는 입사파랑의 직접적인 영향을 받기도 하고 안벽에 의한 반 사파 및 중복파의 영향을 받게 되므로 동요 계산은 여러 개 의 파고 및 주기 성분이 다양한 입사각도로 선체에 작용하는 현상을 시뮬레이션하게 된다. 계류선박에 대한 입사파의 방 향은 입사파 및 반사파의 선체 입사각도를 반영하여 $15^{\circ}, 45^{\circ}$,

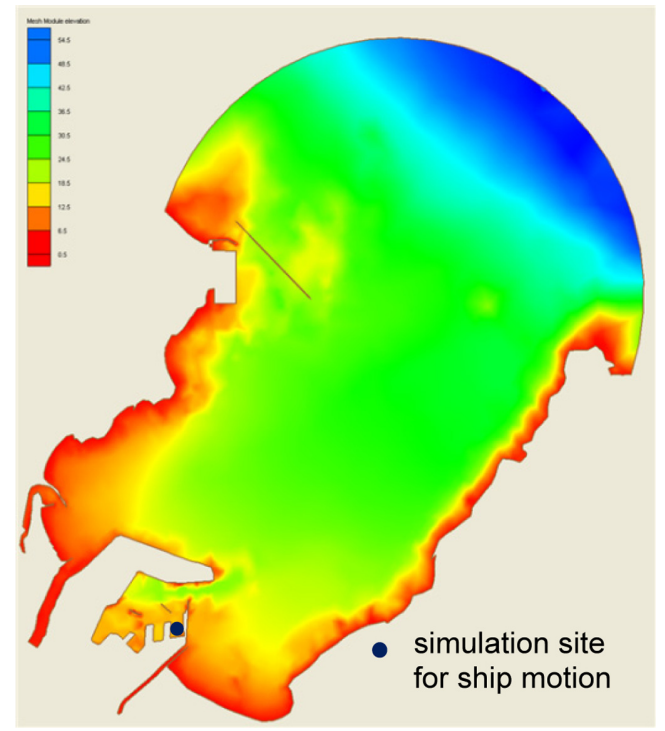

Fig. 2. Bathymetry of Youngil-man area using wave field analysis and the simulation site for ship motion.
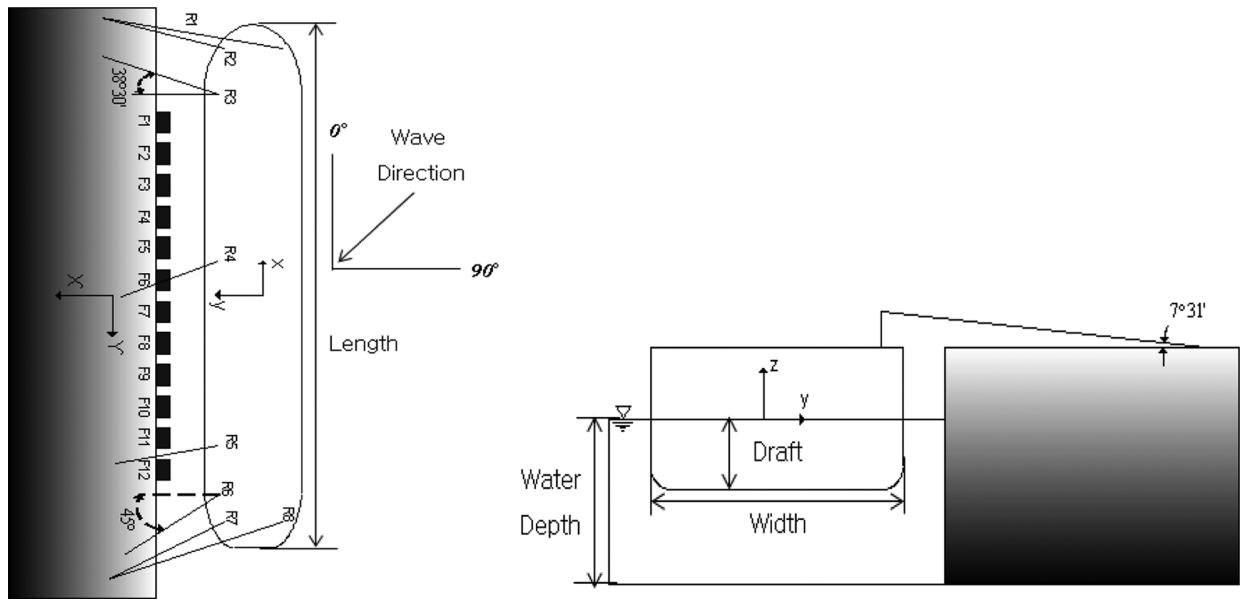

Fig. 3. Definition sketches of the mooring systems and wave direction. 
$75^{\circ}$ 로 선정 하였다. 단주기 파랑조건의 주기는 $8,9,10,11$, $12 \mathrm{~s}$ 로 하였고, 파고는 $0.2 \sim 1.0 \mathrm{~m}$ 의 범위로 하였다. 이는 항내 파랑관측자료(Pohang Regional Maritime Affairs and Port

Table 2. Ship and mooring conditions for simulation of Pohang new harbor.

\begin{tabular}{cccc}
\hline \hline Type of ship & \multicolumn{3}{c}{ General cargo ship } \\
\hline Weight (ton) & 5,000 & 10,000 & 30,000 \\
Length (m) & 98 & 120 & 171.6 \\
Width (m) & 14.0 & 17.42 & 26.0 \\
Draft (m) & 4.5 & 6.0 & 7.0 \\
Wetted area (m ${ }^{2}$ ) & 2534.39 & 3876.04 & 4461.60 \\
$\begin{array}{c}\text { Mooring lines (ea) } \\
\text { Initial tension of } \\
\text { the mooring rope (ton) }\end{array}$ & 8 & 8 & 8 \\
$\begin{array}{c}\text { Modulus elasticity of } \\
\text { the mooring rope } \\
\text { (ton/m) }\end{array}$ & 7.50 & 2.20 & 3.50 \\
$\quad \begin{array}{c}\text { Fenders (ea) } \\
\text { Initial tension of } \\
\text { the fenders (ton) }\end{array}$ & $-1.05 \sim-2.71$ & $-1.05 \sim-2.71$ & $-1.05 \sim-2.71$ \\
$\begin{array}{c}\text { Modulus elasticity of } \\
\text { the fender (ton/m) }\end{array}$ & 130.0 & 130.0 & 130.0 \\
\begin{tabular}{c} 
Basin depth (m) \\
\hline
\end{tabular} & 10.0 & 10.0 & 10.0 \\
\hline
\end{tabular}

Table 3. Short waves conditions for simulation of Pohang new harbor

\begin{tabular}{cc}
\hline \hline \multicolumn{3}{c}{ Short waves conditions } \\
\hline $\mathrm{H}_{\mathrm{s}}(\mathrm{m})$ & $0.2,0.3,0.4,0.5,0.6,0.7,1.0$ \\
$\mathrm{~T}_{\mathrm{s}}(\mathrm{s})$ & $8,9,10,11,12$ \\
Wave direction $\left({ }^{\circ}\right)$ & $15,45,75$ \\
\hline \multicolumn{2}{c}{ Long wave condition } \\
\hline $\mathrm{H}_{\mathrm{s}}(\mathrm{m})$ & 0.12 \\
$\mathrm{~T}_{\mathrm{s}}(\mathrm{s})$ & 60 \\
Wave direction $\left({ }^{\circ}\right)$ & 15 \\
\hline
\end{tabular}

Office, 2010)로부터 얻어진 하역중단 시 관측파랑의 분석 결 과를 이용한 것이다. 또한 장주기 파랑 조건은 CG WAVE모 형(Demirbilek and Panchang, 1998)을 이용하여 포항신항에 대한 항만 공진해석을 실시하고 그 결과로부터 제 8 부두의 공 진주기인 동시에 대상선박의 고유주기인 주기 $60 \mathrm{~s}$ 의 파랑을 선정하였으며, 이 때 파고 $0.12 \mathrm{~m}$ 는 하역중단 시 파랑 관측자 료의 장주기 파 분석 결과를 이용한 것이다(Table 3). 포항신 항의 공진해석 결과는 Kwak et al. (2013)에 제시되어 있다.

\section{2 동요량 계산 결과}

4.2.1 단주기 파랑만 고려한 경우

단주기 파랑만 고려한 경우는 주기 8 12 s의 단주기 파랑이 선체에 입사할 때 동요량을 계산한 것이다. 계산 예로써, 파 랑이 10,000 톤 선박에 $75^{\circ}$ 의 각도로 입사한 경우에 대하여 각 동요 성분별로 유의파고와 동요량의 관계를 나타내면 Fig. 4 와 같다. 그림에서 점선은 Ueda and Shiraisi (1988)가 제안한 하역허용동요량을 나타낸다. 하역허용동요량의 의미는 선박의 동요량이 하역허용동요량을 초과하지 않을 때는 하역이 가능 하고, 허용동요량을 초과하면 하역이 불가능함을 정량적인 수 치로 제안한 것이다.

동요량의 변화를 보면 동일 유의파고에서는 파 주기가 길 어질수록 동요량이 커지는 경향을 보인다. roll의 경우는 주 기 8 9 s에서는 주기가 길어질수록 동요량이 큰 폭으로 증가 하며, 11 12 s에서는 주기변화에 따른 동요량의 증가 폭이 작 아졌다. 또한, 동일 주기에서는 파랑이 선박의 측면으로부터 입사 할 수록 동요량이 커지며 이때 주요 동요성분은 sway, roll인 것을 알 수 있다.

\subsection{2 장 - 단주기 파랑을 고려한 경우}

장·단주기 파랑을 고려한 경우는 단주기 파랑과 장주기 파 랑이 선체에 동시에 작용할 때의 동요량을 계산한 것이다. 선 박의 선형과 계류조건은 단주기 파랑만 계산한 경우와 동일
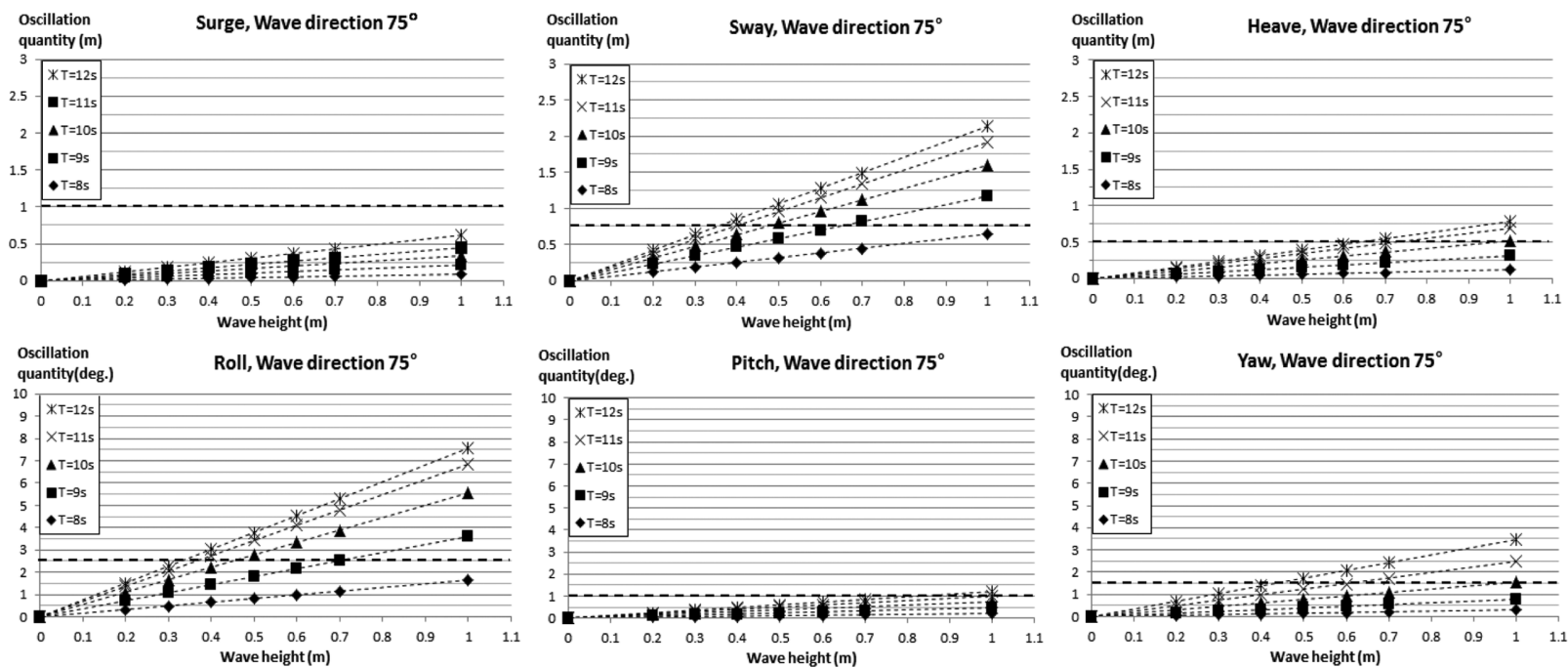

Fig. 4. Computer simulation results of oscillation quantity excited by short waves $\left(10,000\right.$ ton, wave direction of $\left.75^{\circ}\right)$. 
하다. 계산 결과는 10,000 톤 선박에 단주기 파랑이 $75^{\circ}$ 로 입 사하는 경우에 대하여 각 동요 성분별로 유의파고와 동요량 의 관계를 그래프로 도시하여 Fig. 5에 나타내었다.

계산 결과는 파 주기가 길고 유의파고가 클 수록 동요량이 증가하게 되며, 입사각이 커질 수록 동요량이 증가하였다. 특 히, Surge 성분은 단주기 파랑만 고려한 경우는 주기와 파고 가 커짐에 따라 동요량이 완만하게 증가하였으나, 장주기 파 랑이 동시에 작용하면 단주기 파랑의 주기와 파고에 관계없 이 일정한 값을 나타내었다. 이것은 대상선박의 surge 동요 고 유주기가 장주기 파랑과 상호작용을 일으키어 surge 동요를 더 욱 크게 증가시킨 결과로 생각된다.

\section{5. 현지 항만의 하역한계파고 산정}

\section{1 장주기 파랑을 고려한 하역한계파고 산정 방법}

장주기 파랑이 항내로 내습할 경우 항만 공진 현상이 발 생하고 특정 공진 주기가 선박의 고유주기와 일치하면 동
요량이 크게 증가하므로 하역한계파고는 감소한다. 선박의 하역한계파고는 단주기 파뿐만 아니라 장주기 파랑을 고려 하여 산정하여야만 실제 현상에 근접한 결과를 얻을 수 있 다. 본 연구에서는 장주기 파랑에 의한 선박 동요량 및 하 역한계파고를 Fig. 6과 같이 산정하였다. 먼저 CGWAVE모 형을 사용하여 항만 공진해석을 실시하고 공진주기와 그 때 의 진폭을 찾아내었다. 다음은 공진해석에서 찾아낸 주기와 진폭을 선박 동요 해석모형의 장주기 파랑조건으로 사용하 였다. 그리고 여기서는 각 선형마다 장단주기 파랑조건 및 계류조건을 다르게 하여 장주기 파 및 단주기 파가 선체에 작용하는 힘, 즉 동유체력을 각각 계산하고 다시 이들을 합 성하여 선체에 작용하는 외력으로 부여하였다. 동요 시뮬레 이션으로부터 얻어진 계류선박의 동요량은 입사파고에 대응 하는 동요량의 변화를 그래프로 표시하고, 각 주기별로 파 고와 동요량과의 회귀식을 구하였다. 그 다음 단계는 앞에 서 설명한 하역한계파고 산정 방법과 동일한 과정으로 진 행된다.
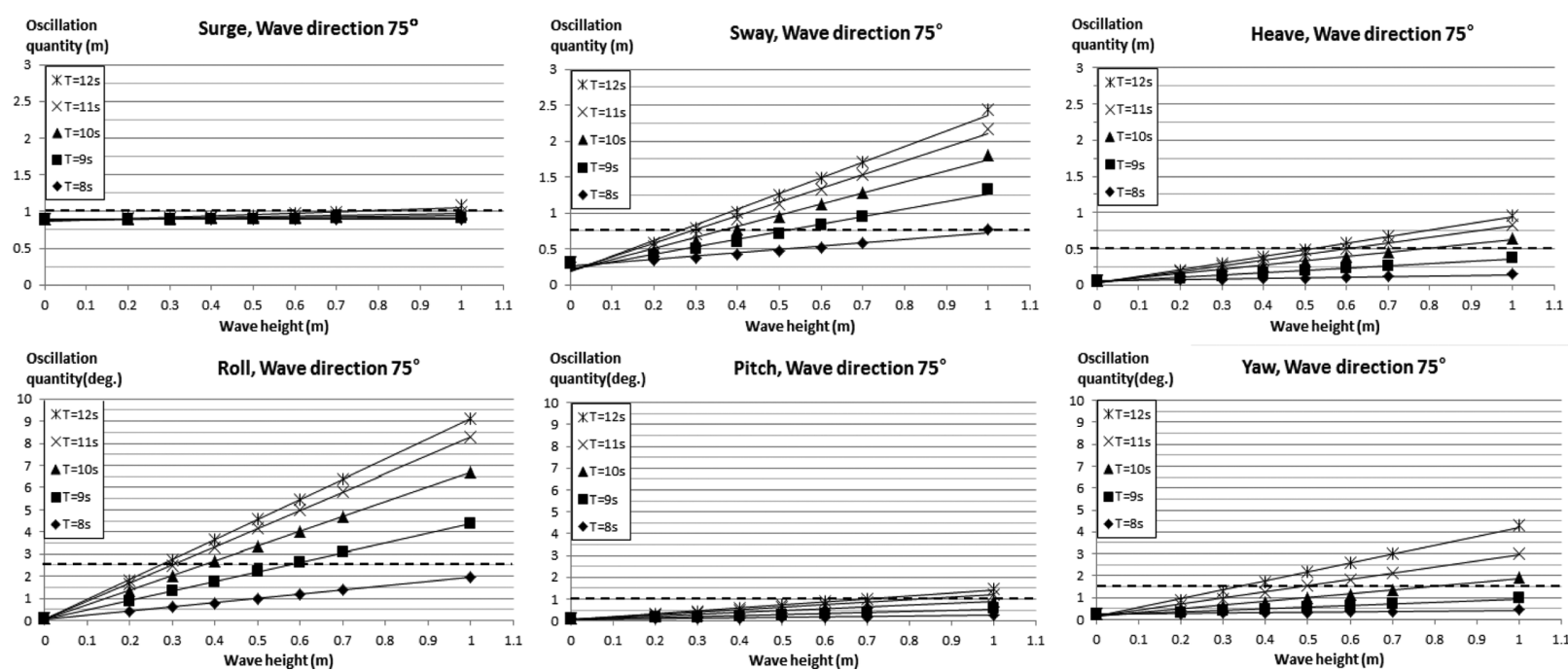

Fig. 5. Computer simulation results of oscillation quantity excited by short and long waves $\left(10,000\right.$ ton, wave direction of $\left.75^{\circ}\right)$.

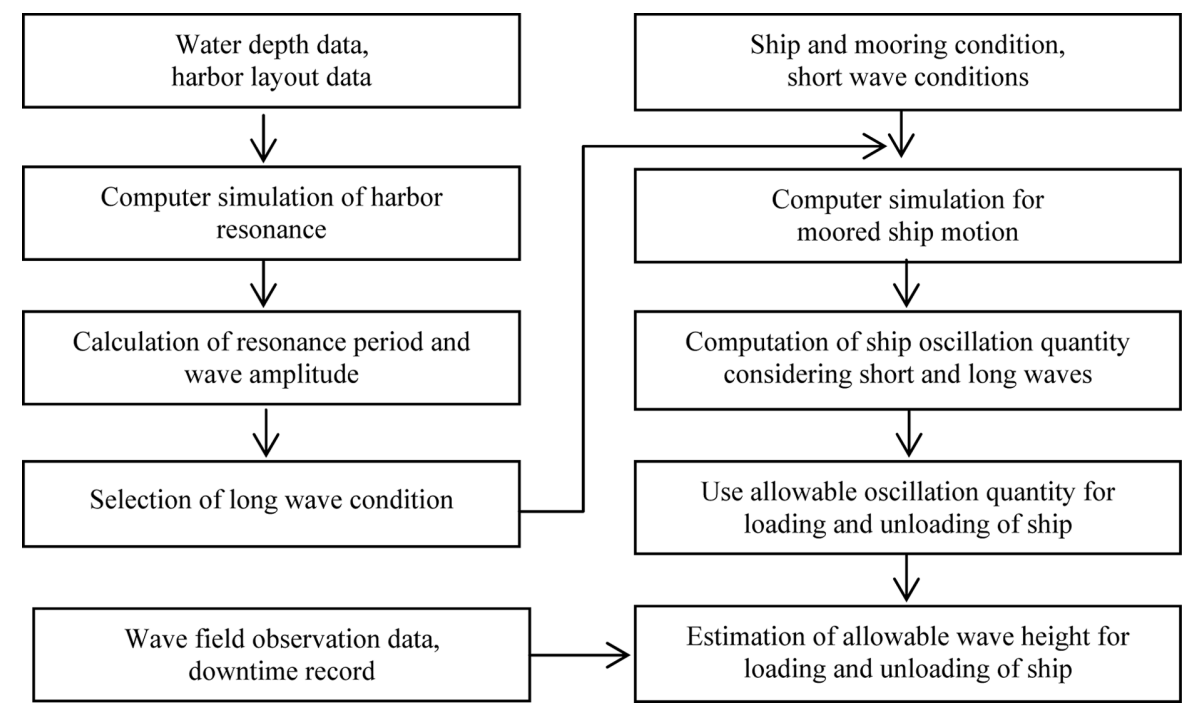

Fig. 6. Computation process on allowable wave height for loading and unloading of the ship considering ship motion excited by long waves. 


\section{2 포항신항의 하역한계파고 산정 결과}

본 연구에서는 포항신항 제 8 부두의 항내 슬립에 5,000 톤, 10,000 톤, 30,000 톤의 선박이 계류되었을 경우를 상정하고, 단 주기 파랑만 고려한 경우와 장단주기 파랑을 고려한 경우의 하역한계파고를 산정하였다.

Table 4는 5,000톤에 대한 결과로써 단주기 파랑은 $0.27 \sim 0.50 \mathrm{~m}$, 장단주기 파랑은 $0.19 \sim 0.50 \mathrm{~m}$ 로 산정되었다. 그 리고 Table 5 는 10,000 톤에 대한 결과로써 단주기 파랑은 $0.33 \sim 0.50 \mathrm{~m}$, 장단주기 파랑은 $0.22 \sim 0.50 \mathrm{~m}$ 로 산정되었다. 또 한 Table 6은 30,000 톤에 대한 결과로써 단주기 파랑은 $0.50 \mathrm{~m}$, 장단주기 파랑은 $0.42 \sim 0.50 \mathrm{~m}$ 로 산정되었다.

본 방법에 의한 결과는 입사파의 주기가 $12 \mathrm{~s}$ 일 때 $0.19 \sim 0.50 \mathrm{~m}$ 로서 설계기준 대비 $16 \sim 62 \%$ 감소하였다. 이러한 결과는 항만 설계시 항내정온도가 설계기준에는 만족할 지라 도 선박 동요량의 증가로 인하여 하역중단 사례가 발생할 수 있음을 보여주는 것이다.

또한, 본 모형의 결과는 입사파의 주기가 $12 \mathrm{sec}$ 인 경우, 입 사 각이 $15^{\circ}$ 일 때는 설계기준 대비 $0 \sim 4 \%$ 감소하였고, 입사 각이 $45^{\circ}$ 일 때는 10 50\%, $75^{\circ}$ 일 때는 16 62\%감소하였다. 따 라서, 본 방법에 의한 하역한계파고는 선형이 작을 수록, 입사 파 주기와 입사 각도가 클 수록 설계기준 보다 더욱 감소하였 다. 이것은 현행 설계기준은 선형, 입사파의 주기, 입사각도와 무관하게 산정되었지만, 본 방법은 선형, 입사파의 주기 및 입 사각도 등을 반영하여 하역한계파고를 산정하였기 때문이다.

Table 4. Results of allowable wave height for loading and unloading with change of wave periods and directions at pier 8 in Pohang new harbor (5,000 ton, unit in meter)

\begin{tabular}{cccccc}
\hline \hline wave period (s) & 8 & 9 & 10 & 11 & 12 \\
\hline short and long wave $\left(75^{\circ}\right)$ & 0.50 & 0.39 & 0.25 & 0.22 & 0.19 \\
short and long wave $\left(45^{\circ}\right)$ & 0.50 & 0.50 & 0.42 & 0.30 & 0.25 \\
short and long wave $\left(15^{\circ}\right)$ & 0.50 & 0.50 & 0.42 & 0.32 & 0.28 \\
short wave only $\left(75^{\circ}\right)$ & 0.50 & 0.50 & 0.35 & 0.30 & 0.27 \\
short wave only $\left(45^{\circ}\right)$ & 0.50 & 0.50 & 0.48 & 0.35 & 0.30 \\
short wave only $\left(15^{\circ}\right)$ & 0.50 & 0.50 & 0.48 & 0.37 & 0.32 \\
design standards & 0.50 & 0.50 & 0.50 & 0.50 & 0.50 \\
\hline
\end{tabular}

Table 5. Results of allowable wave height for loading and unloading with change of wave periods and directions at pier 8 in Pohang new harbor (10,000 ton, unit in meter)

\begin{tabular}{cccccc}
\hline \hline wave period $(\mathrm{s})$ & 8 & 9 & 10 & 11 & 12 \\
\hline short and long wave $\left(75^{\circ}\right)$ & 0.50 & 0.50 & 0.32 & 0.25 & 0.22 \\
short and long wave $\left(45^{\circ}\right)$ & 0.50 & 0.50 & 0.50 & 0.38 & 0.33 \\
short and long wave $\left(15^{\circ}\right)$ & 0.50 & 0.50 & 0.50 & 0.40 & 0.35 \\
short wave only $\left(75^{\circ}\right)$ & 0.50 & 0.50 & 0.45 & 0.36 & 0.33 \\
short wave only $\left(45^{\circ}\right)$ & 0.50 & 0.50 & 0.50 & 0.45 & 0.39 \\
short wave only $\left(15^{\circ}\right)$ & 0.50 & 0.50 & 0.50 & 0.48 & 0.42 \\
design standards & 0.50 & 0.50 & 0.50 & 0.50 & 0.50 \\
\hline
\end{tabular}

한편, 단주기 파랑만 고려한 경우와 장단주기 파랑을 모두 고려했을 때의 하역한계파고를 설계기준 파고와 비교하면 Fig. 7 9와 같다. 그림에서 회색 실선은 설계기준을 나타내고, 마 크된 실선은 단주기 파랑만 고려한 경우, 마크된 점선은 장 단주기 파랑을 고려한 경우의 하역한계파고를 나타낸다. Fig. 7 은 5,000톤에 대한 결과로써 장단주기 파랑을 고려한 경우 는 입사파 주기가 $8 \mathrm{~s}$ 이후부터 설계기준보다 작아지기 시작 하여 주기 $12 \mathrm{~s}$ 일 때는 파향별로 $0.19 \sim 0.28 \mathrm{~m}$ 를 나타내며, 단 주기 파랑만 고려한 경우는 입사파 주기가 $9 \mathrm{~s}$ 이후부터 설계 기준보다 작아지기 시작하여 주기 $12 \mathrm{~s}$ 일 때는 파향별로 $0.27 \sim 0.32 \mathrm{~m}$ 를 나타내었다. 그리고 Fig. 8은 10,000톤에 대한 결과로써, 장단주기 파랑을 고려한 경우는 입사파 주기 $9 \mathrm{~s}$ 이 후부터 설계기준보다 작아지기 시작하여 주기 $12 \mathrm{~s}$ 일 때는 $0.22 \sim 0.35 \mathrm{~m}$ 를 나타내며, 단주기 파랑만 고려한 경우는 주기 $12 \mathrm{~s}$ 일 때 $0.33 \sim 0.42 \mathrm{~m}$ 를 나타내었다. 또한 Fig. 9는 30,000 톤에 대한 결과로써, 장단주기 파랑을 고려한 경우는 입사파 주기 $11 \mathrm{~s}$ 이후부터 설계기준보다 작아지기 시작하여 주기 $12 \mathrm{~s}$ 일 때는 0.42 0.50 m를 나타내며, 단주기 파랑만 고려한 경 우는 모든 주기 설계기준보다 큰 값을 나타내었다.

여기서 장주기 파랑이 하역한계파고에 미치는 영향을 파악 하기 위하여 입사파 주기가 $12 \mathrm{sec}$ 일 때, 장주기 파랑의 고려 유무에 따른 하역한계파고 결과를 비교하였다. 장주기 파랑 을 고려한 경우는 고려하지 않은 경우보다 5,000 톤은 $8 ~ 16 \%$, 10,000 톤은 $14 \sim 22 \%, 30,000$ 톤은 $10 \sim 16 \%$ 더 감소하였다. 특 히, 30,000 톤의 결과는 주기 $12 \mathrm{~s}$ 일 때 단주기 파랑만 계산

Table 6. Results of allowable wave height for loading and unloading with change of wave periods and directions at pier 8 in Pohang new harbor (30,000 ton, unit in meter)

\begin{tabular}{cccccc}
\hline \hline wave period (s) & 8 & 9 & 10 & 11 & 12 \\
\hline short and long wave $\left(75^{\circ}\right)$ & 0.50 & 0.50 & 0.50 & 0.50 & 0.42 \\
short and long wave $\left(45^{\circ}\right)$ & 0.50 & 0.50 & 0.50 & 0.50 & 0.45 \\
short and long wave $\left(15^{\circ}\right)$ & 0.50 & 0.50 & 0.50 & 0.50 & 0.50 \\
short wave only $\left(75^{\circ}\right)$ & 0.50 & 0.50 & 0.50 & 0.50 & 0.50 \\
short wave only $\left(45^{\circ}\right)$ & 0.50 & 0.50 & 0.50 & 0.50 & 0.50 \\
short wave only $\left(15^{\circ}\right)$ & 0.50 & 0.50 & 0.50 & 0.50 & 0.50 \\
design standards & 0.50 & 0.50 & 0.50 & 0.50 & 0.50 \\
\hline
\end{tabular}

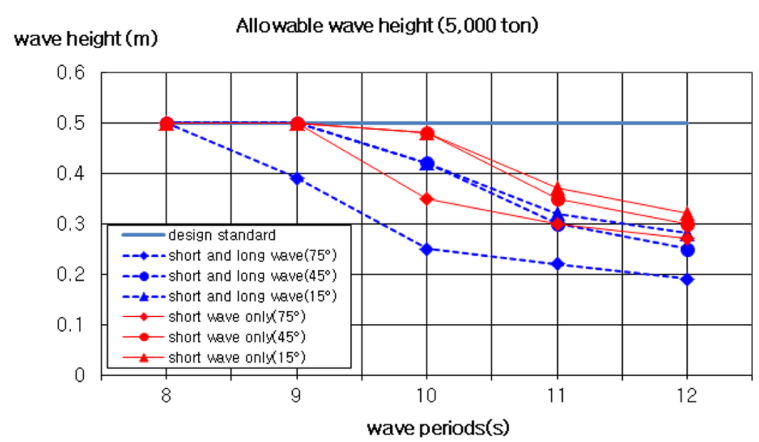

Fig. 7. Results of comparison between design standards and computer simulation $(5,000$ ton). 


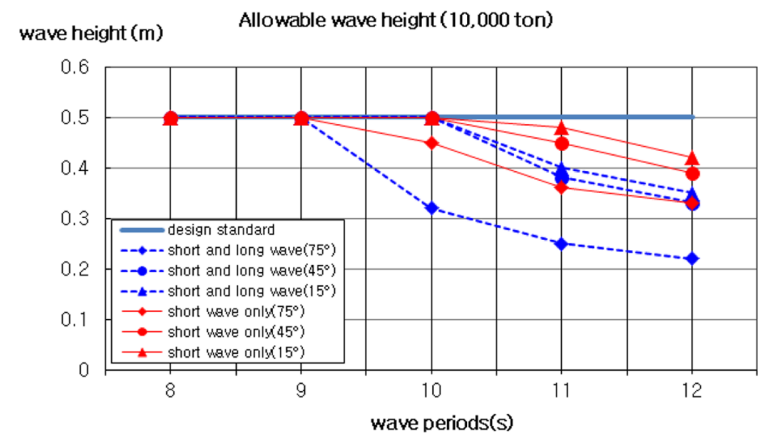

Fig. 8. Results of comparison between design standards and computer simulation (10,000 ton).

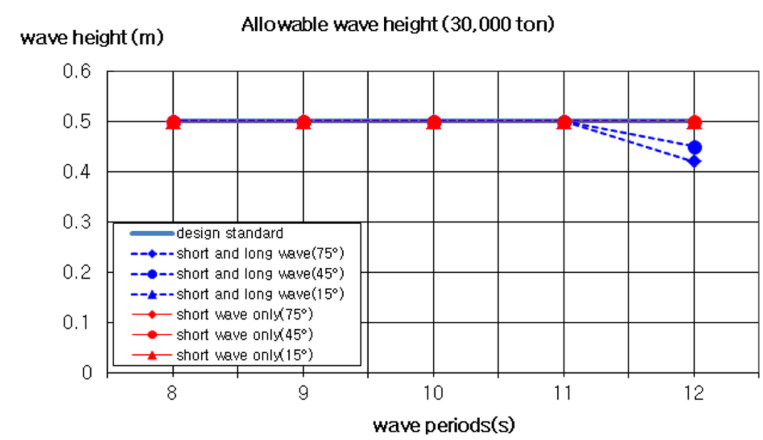

Fig. 9. Results of comparison between design standards and computer simulation (30,000 ton).

하면 설계기준보다 크게 산정되지만, 장주기 파랑을 고려하 면 설계기준보다 작게 산정됨을 알 수 있다. 따라서, 선박이 중대형선인 경우는 장주기 파랑에 의한 동요량 증가가 하역 한계파고 산정에 매우 중요하게 작용함을 알 수 있다.

\section{3 하역중단 시 파랑 관측자료와의 비교}

본 연구에서는 포항지방해양항만청에서 실시한 대규모 항 내외 파랑관측으로부터 얻어진 자료(Pohang Regional Maritime Affairs and Port Office, 2010; Jeong et al., 2011) 중, 제 8 부두의 항내 슬립에서 하역중단 시 관측된 파 랑자료를 분석하고 본 방법에 의한 하역한계파고 산정결과와
비교하여 그 타당성을 검토하였다.

Table 7은 입사각이 $75^{\circ}$ 인 경우에 대해서 본 방법에 의한 하 역한계파고 산정 결과와 현지 파랑관측 자료를 비교한 것이다. 표에는 하역중단시기, 선형, 하역중단 시 관측된 파고 및 주기 를 표시하였다. 또한 본 방법에 의한 하역한계파고는 단주기 파랑만을 고려한 경우와 장단주기 파랑을 고려한 경우의 결과 를 선박의 크기별로 정리하였고, 설계기준도 표시하였다.

포항신항 제 8부두의 항내 슬립에서 2008년 11월부터 2009 년 1월까지 발생한 하역중단 사례는 대상선박이 1,200 톤 $\sim 35,000$ 톤이었으며, 하역중단 시 관측된 파랑은 단주기 성분 의 경우 파고 $0.10 \sim 0.75 \mathrm{~m}$, 주기 $8 \sim 16 \mathrm{~s}$ 이었고, 장주기 성분은 파고 $0.10 \sim 0.20 \mathrm{~m}$, 주기 $48 \sim 60 \mathrm{~s}$ 이었다. 그리고 본 방법에 의 한 하역한계파고는 5,000 톤, 10,000 톤, 30,000 톤에 대한 결과 로써 단주기 파랑만 고려한 경우는 파고 $0.27 \sim 0.50 \mathrm{~m}$, 주기 $8 \sim 12 \mathrm{~s}$ 이며, 장단주기 파랑을 고려한 경우는 파고 $0.19 \sim 0.50 \mathrm{~m}$, 주기 8 12 s이다. 여기서 본 방법에 사용된 장주기 성분은 주 기 $60 \mathrm{~s}$, 파고 $0.12 \mathrm{~m}$ 이다. 따라서 본 방법에 의한 하역한계파 고는 장주기 성분을 고려한 경우가 고려하지 않은 경우 보다 관측치에 더욱 근접하였다. 그리고 하역중단이 발생한 실제 선 박의 크기가 본 연구대상의 선박 크기와 정확히 일치하지는 않으며, 현지 기상악화로 인한 강우 및 강한 바람이 하역중단 에 영향을 미친 경우도 있어서 두 결과 사이에 오차는 발생 하였지만 본 방법에 의한 하역한계파고는 선형 및 주기에 따 라 관측치를 잘 재현하고 있음을 알 수 있다.

한편 설계기준의 하역한계파고는 관측기간 동안 하역중단이 발생한 모든 선박의 크기가 중대형선에 속하여 일률적으로 $0.5 \mathrm{~m}$ 로 적용되며, 이는 선형 및 주기에 따라 크게 변하는 실 제 하역중단 시 파고와는 많은 차이가 있다.

\section{6. 항만가동률 산정}

본 연구에서는 2008년 08월 23일부터 2009년 08월 26일 까지 1년간 포항 신항 외해 측에서 관측된 평상시 파랑자료

Table 7. Results of comparison between field data and computer simulation in case of wave direction of $75^{\circ}$

\begin{tabular}{ccccccc}
\hline \hline \multirow{2}{*}{ Downtime duration } & $\begin{array}{c}\text { Field ship } \\
\text { sizes (ton) }\end{array}$ & $\begin{array}{c}\text { Field data } \\
\left(H_{s}, T_{p}\right)\end{array}$ & Short waves $\left(H_{s}, T_{s}\right)$ & $\begin{array}{c}\text { Short and long waves } \\
\left(H_{s}, T_{s}\right)\end{array}$ & $\begin{array}{c}\text { Simulated ship } \\
\text { sizes(ton) }\end{array}$ & $\begin{array}{c}\text { Technical } \\
\text { standards }\end{array}$ \\
\cline { 5 - 7 } & & & & & & \\
$2008 / 11 / 09 \sim 11 / 11$ & 3,500 & $0.35 \sim 0.45 \mathrm{~m}, 8 \sim 16 \mathrm{~s}$ & $0.27 \sim 0.50 \mathrm{~m}, 8 \sim 12 \mathrm{~s}$ & $0.19 \sim 0.50 \mathrm{~m}, 8 \sim 12 \mathrm{~s}$ & 5,000 & $0.50 \mathrm{~m}$ \\
$2008 / 11 / 28 \sim 11 / 29$ & $3,500 \sim 22,000$ & $0.15 \sim 0.38 \mathrm{~m}, 8 \sim 10 \mathrm{~s}$ & $0.27 \sim 0.50 \mathrm{~m}, 8 \sim 12 \mathrm{~s}$ & $0.19 \sim 0.50 \mathrm{~m}, 8 \sim 12 \mathrm{~s}$ & $5,000 \sim 30,000$ & $0.50 \mathrm{~m}$ \\
$2008 / 12 / 14 \sim 12 / 15$ & 3,700 & $0.10 \sim 0.38 \mathrm{~m}, 7 \sim 10 \mathrm{~s}$ & $0.27 \sim 0.50 \mathrm{~m}, 8 \sim 12 \mathrm{~s}$ & $0.19 \sim 0.50 \mathrm{~m}, 8 \sim 12 \mathrm{~s}$ & 5,000 & $0.50 \mathrm{~m}$ \\
$2008 / 12 / 18 \sim 12 / 20$ & $800 \sim 2,500$ & $0.10 \sim 0.50 \mathrm{~m}, 8 \sim 12 \mathrm{~s}$ & $0.27 \sim 0.50 \mathrm{~m}, 8 \sim 12 \mathrm{~s}$ & $0.19 \sim 0.50 \mathrm{~m}, 8 \sim 12 \mathrm{~s}$ & 5,000 & $0.50 \mathrm{~m}$ \\
$2008 / 12 / 21 \sim 12 / 23$ & $4,500 \sim 17,000$ & $0.15 \sim 0.65 \mathrm{~m}, 8 \sim 11 \mathrm{~s}$ & $0.27 \sim 0.50 \mathrm{~m}, 8 \sim 12 \mathrm{~s}$ & $0.19 \sim 0.50 \mathrm{~m}, 8 \sim 12 \mathrm{~s}$ & $5,000 \sim 30,000$ & $0.50 \mathrm{~m}$ \\
$2008 / 12 / 28 \sim 12 / 29$ & 8,500 & $0.15 \sim 0.25 \mathrm{~m}, 9 \sim 11 \mathrm{~s}$ & $0.33 \sim 0.50 \mathrm{~m}, 8 \sim 12 \mathrm{~s}$ & $0.22 \sim 0.50 \mathrm{~m}, 8 \sim 12 \mathrm{~s}$ & 10,000 & $0.50 \mathrm{~m}$ \\
$2008 / 12 / 31 \sim 2009 / 1 / 4$ & $2,500 \sim 26,000$ & $0.15 \sim 0.40 \mathrm{~m}, 9 \sim 12 \mathrm{~s}$ & $0.27 \sim 0.50 \mathrm{~m}, 8 \sim 12 \mathrm{~s}$ & $0.19 \sim 0.50 \mathrm{~m}, 8 \sim 12 \mathrm{~s}$ & $5,000 \sim 30,000$ & $0.50 \mathrm{~m}$ \\
$2009 / 01 / 09 \sim 01 / 15$ & $1,500 \sim 35,000$ & $0.10 \sim 0.50 \mathrm{~m}, 9 \sim 13 \mathrm{~s}$ & $0.27 \sim 0.50 \mathrm{~m}, 8 \sim 12 \mathrm{~s}$ & $0.19 \sim 0.50 \mathrm{~m}, 8 \sim 12 \mathrm{~s}$ & $5,000 \sim 30,000$ & $0.50 \mathrm{~m}$ \\
$2009 / 01 / 30 \sim 02 / 02$ & $1,200 \sim 30,000$ & $0.15 \sim 0.75 \mathrm{~m}, 7 \sim 12 \mathrm{~s}$ & $0.27 \sim 0.50 \mathrm{~m}, 8 \sim 12 \mathrm{~s}$ & $0.19 \sim 0.50 \mathrm{~m}, 8 \sim 12 \mathrm{~s}$ & $5,000 \sim 30,000$ & $0.50 \mathrm{~m}$ \\
\hline
\end{tabular}


Table 8. The rate of effective working days at Pier 8 in Pohang New harbor

\begin{tabular}{|c|c|c|c|c|}
\hline \multirow{2}{*}{$\begin{array}{c}\text { Ship size } \\
\text { (DWT) }\end{array}$} & \multirow{2}{*}{$\begin{array}{c}\text { Design } \\
\text { standard } \\
(\%)\end{array}$} & \multicolumn{2}{|c|}{ Considering ship motion } & \multirow{2}{*}{$\begin{array}{c}\text { Wave } \\
\text { direction } \\
\left({ }^{\mathrm{o}}\right)\end{array}$} \\
\hline & & Short waves (\%) & $\begin{array}{l}\text { Including long } \\
\text { waves (\%) }\end{array}$ & \\
\hline \multirow{3}{*}{5,000} & \multirow{3}{*}{100} & 97.1 & 93.5 & 75 \\
\hline & & 98.0 & 96.7 & 45 \\
\hline & & 98.7 & 97.9 & 15 \\
\hline \multirow{3}{*}{10,000} & \multirow{3}{*}{100} & 99.1 & 94.6 & 75 \\
\hline & & 99.4 & 98.8 & 45 \\
\hline & & 99.5 & 99.0 & 15 \\
\hline \multirow{3}{*}{30,000} & \multirow{3}{*}{100} & 100.0 & 99.5 & 75 \\
\hline & & 100.0 & 99.7 & 45 \\
\hline & & 100.0 & 100.0 & 15 \\
\hline
\end{tabular}

(Pohang Regional Maritime Affairs and Port Office, 2010)를 사용하여 제 8 부두 안쪽의 항내 슬립에서 항만가동율 을 산정하였다.

Table 8은 5000톤, 10000 톤, 30000 톤 선박에 $15,45,75$ 도의 파랑이 입사할 때 가동율을 산정한 것이다. 가동율 결 과는 현행 항만설계기준을 적용한 결과와 단주기 파랑만 작 용했을 때의 선박동요량에 의한 결과, 그리고 장단주기 파랑 에 의한 선박동요를 고려한 경우에 대하여 비교하였다.

현행 설계기준에 의한 가동율은 모든 선박에서 입사 파향 에 관계없이 항내정온도 조건을 만족하였다. 그리고 단주기 파랑만 작용 했을 때 선박동요량을 고려한 경우는 30,000 톤 선박에 대해서는 $100 \%$ 를 나타내었고, 10,000 톤 선박은 $99.1 \sim 100 \%$ 를 나타내었으며, 5,000톤 선박의 경우는 97.1 98.7\%로 항내정온도를 만족하지 경우도 나타났다.

한편 장단주가 파랑이 작용했을 때 선박동요량을 고려한 경 우는 30,000 톤 선박은 $99.5 \sim 100 \%, 10,000$ 톤 선박은 94.6 99.0\%, 5,000톤 선박은 93.5 97.9\%를 나타내었다. 따 라서 선박동요량을 고려한 가동율 결과는 10,000 톤 이하에서 항내정온도를 만족하지 못하였으며, 특히 5,000 톤 선박의 가 동율은 설계기준을 적용한 결과보다 최대 $6.5 \%$ 낮은 가동율 을 나타내어서 항내정온도 기준에 크게 미치지 못하는 것을 알 수 있다.

\section{7. 결 론}

본 연구에서는 선박의 크기, 계류상태, 단주기 및 장주기 파 의 영향을 반영하여 선박 동요량을 계산하고 하역한계파고를 산정하는 방법을 제시하였으며, 포항신항의 제8부두에 본 방 법을 적용한 결과 하역중단 시 현지 파랑관측 자료를 잘 재 현 하였다. 그리고 본 연구를 통하여 다음과 같은 사실을 확 인하였다.

(1) 본 방법에 의한 하역한계파고는 선형 및 선체 입사파 의 주기 변화에 대응하여 실제 하역한계파고를 잘 재현하였
다. 한편 설계기준에 제시된 하역한계파고는 선형 및 주기 변 화에 따라 대응하지 못함을 알 수 있다. 특히 10,000 톤 이하 의 하역한계파고는 선박동요량을 고려하면 설계기준보다 작 아지며, 장주기 파랑을 고려하면 더욱 작아진다.

(2) 본 방법에 의한 결과는 5,000 톤, 10,000 톤, 30,000 톤 선박에 대해서 장주기 파를 고려하면 설계기준의 하역한계파 고에 비해서 16 62\%감소하였고, 장주기 파를 고려하지 않으 면 $0 \sim 46 \%$ 감소하였다. 특히 30,000 톤의 결과는 단주기 파랑 만 작용할 때는 설계기준을 만족하였지만, 장주기 파랑이 작 용할 때는 설계기준보다 감소하였다. 이러한 결과는 항만 설 계시 현행 설계기준을 적용하면 항내 정온도가 만족될 지라 도 장주기 파랑이 선박의 동요량을 증가시켜서 하역불능 사 례를 발생시킬 수도 있음을 나타낸 것이다.

(3) 포항신항 제 8 부두에서 5,000톤, 10,000 톤, 30,000 톤에 대한 항만가동율 산정 결과는 현행 설계기준을 적용하면 $100 \%$ 를 나타내지만, 선박동요량을 고려하면 93.5 100\%를 나 타내었다. 특히 10,000 톤 이하의 가동율은 선박동요량을 고 려하면 현행 설계기준을 적용한 결과보다 뚜렷이 작아지며 장 주기 파랑을 고려하면 더욱 작아짐을 알 수 있다.

(4) 본 방법은 선형, 계류상태, 선체 입사파의 주기 및 입 사 각도에 대응하여 하역한계파고를 산정할 수 있으므로 항 내 정온도 평가 및 하역가동률 산정 시 보다 현실적인 결과 를 도출하는데 매우 유용한 방법이 될 수 있을 것이다. 또한 본 방법의 정확도를 더욱 높이기 위해서는 향후 선박동요의 현지 계측 및 하역중단 시 현지 파랑 관측 자료의 축적이 필 요하다.

\section{감사의 글}

본 논문은 한국연구재단의 지원을 받아 수행된 기초연구사 업(N0. 2010-0023136)의 연구결과 중 일부 임.

\section{References}

Ann, S. P. (1986). Analysis of Moored Ship Motion Using Three Dimensional Source Distribution Method, Master's Thesis, Seoul National University, Seoul Korea (in Korean).

Ann, S. P. and Rhee, K. P. (1987). "The Hydrodynamic Interaction Effects between Two Barges on the Motion Responses", Journal of the Society of Naval Architects of Korea, 24(1), 29-34 (in Korean).

Bruun, P. (1981) Port Engineering, 3rd Edition, Gulf Pub.

Cho, I. S., Kong, K. Y. and Lee, Y. S. (2006). "A Time Domain Analysis of Moored Ship Motions Considering Tsunami Resonant Effects", Proceedings of the Spring Conference on Korean Institute of Navigation and Port Research, Korean Institute of Navigation and Port Research, 30(1), 191-197 (in Korean).

Demirbilek, Z. and Panchang, V. (1998). CGWAVE : A Coastal 
Surface Water Wave Model of the Mild Slope Equation. Technical Report CHL-98-xx, U.S. Army Corps of Engineers, 6-11.

Jeong, W. M., Ryu, K. H., Beak, W. D. and Choi. H. J. (2011). "Downtime Analysis for Pohang New harbor through Longterm Investigation of Waves and Winds", Journal of Korean Society of Coastal and Ocean Engineers, 23(3), 226-235 (in Korean).

Kubo, M., Saitou, K. and Sakakibara, S. (1988). "Application of a strip method to the hull motion of a quay-front moored vessels", Proceedings of the 35th Japanese Conference on Coastal Engineering, Japan Society of Civil Engineers, Vol. 35, 682-686 (in Japanese).

Kubo, M., Saito, K. and Oki, T. (1993). "Approximate Calculation of Ship Motions under the Prevention System of Ship Separation from Quay Wall”, Journal of Japan Institute of Navigation, Vol. 89, 15-21 (in Japanese).

Kubo, M. and Sakakibara, S. (1995). "Effects of Long Period Waves Caused by Wave Groups and Harbor Oscillation in Computation of Wharf Operation Efficiency", Proceedings of Coastal Engineering, Japan Society of Civil Engineers, Vol. 42, 931-935 (in Japanese).

Kwak, M., Chung, J., Ann, S. and Pyun, C. (2006). "Estimation of Harbor Operating Ratio Based on Moored Ship Motion", Journal of The Korean Society of Civil Engineers, 26(6B), 651-660 (in Korean).

Kwak, M. S., Moon, Y. H. and Pyun, C. K. (2013). A Study on Analysis of Moored Ship Motion Considering Harbor Resonence, Journal of The Korean Society of Civil Engineers, 33(2), 895-608 (in Korean).
Mollen, W., Ligteringen, H., Lem, J. C. vander, Waal, J. C. M. de (2003). "Behavior of a Moored LNG Ship in Swell Waves", Journal of Waterway, Port, Coastal, and Ocean Engineering, ASCE, 129(1), 15-21.

Pohang Regional Maritime Affairs and Port Office (2010). Field Investigation Report for Swell Analysis and Improvement Measure Making of Downtime in Pohang New Harbor, Report of Pohang Regional Maritime Affairs and Port Office (in Korean).

Sakakibara, S., Saitou, K. and Kubo, M. (2001). "A study on LongPeriod Ship Motions in a Harbor Induced by a Resonant Large Roll Motion Under Long-Period Waves", Proceedings of ISOPE, The International Society of Offshore and Polar Engineers, Stavanger Norway, 326-333.

Ueda, S. and Shiraishi, S. (1988). The allowable ship motions for cargo handling at wharves. 27(4), Technical report of port and harbour research Institute, Japan, 3-61 (in Japanese)..

Ueda, S., Shiraishi, S., Oshima, H. and Asano, K. (1994). "Proposal of Allowable Wave Height and Wharf Operation Efficiency Based on the Oscillations of Ships Moored to Quay Walls", Proceedings of Coastal Engineering, Japan Society of Civil Engineers, Vol. 41, 916-920 (in Japanese).

Received 4 December, 2014

Revised 6 February, 2015

Accepted 9 February, 2015 